\title{
FOUCAULT'S ANALYSIS OF POWER'S METHODOLOGIES
}

\section{Gary Alan Scott Siena College}

Part 4 of The Will to Know, where Foucault turns to his most direct treatment of power, contains the often-cited statement, "In political thought and analysis, we have still not cut off the head of the King." I I will contend in what follows that Foucault's notion of power is much more radical than such a beheading implies. By exploring the contrariety between sovereignty and power, I will outline why Foucault's violence against the King is both more subtle and more devastating than would be an overt decapitation of the old monarch.

Before he developed his conception of power, Foucault had already problematized the meaning of sovereignty in his archaeological writings, particularly The Order of Things and The Archaeology of Knowledge. But his discussion of power in The Will to Know renders redundant the King and all other sovereignties of the type he calls "juridico-discursive."

In The Order of Things, for example, Foucault exhibits how the locus of sovereignty shifts in the Classical Age from what we might call a sovereignty of exteriority to a sovereignty of interiority. 2 Its locus shifts again from the Classical Age to the Modern period, from what Foucault calls a "symbolics of blood" to an "analytics of sexuality." 3 On the one hand, Foucault shows how the locus of sovereignty changes in the Classical Age without either its structure being called into question or its theoretical warrant being exhibited; on the other hand, he illustrates just how paradoxical was the Classical model of sovereignty by utilizing the term sovereignty himself in all its richness and ambiguity. He refuses to adhere strictly

I Michel Foucault, The History of Sexuality, Vol. I, trans. Robert Hurley (New York: Random House, 1978), 89. I follow James Miller in referring to this volume as The Will to Know. This is a more literal translation of Foucault's French title, La Volente de savoir. Because Hurley's English translation is entitled The History of Sexuality: Volume I, the notes will reflect this choice. Sec James Miller, The Passion of Michel Foucault (New York: Simon \& Schuster, 1993).

2 I am grateful to John Carvalho of Villanova University for this phraseology and for his many helpful comments on an earlier draft of this paper. I would also like to express my appreciation for the thorough and incisive comments offered by Scolt $M$. Christensen, of the University of California at Riverside, in his formal response to an earlier version of this paper delivered at the APA Pacific Division Meeting in Los Angeles, California on April 2, 1994.

3 The History of Sexuality, V. I, 148. 
to any univocal sense of sovereignty, exploiting the unexamined conceit inherent in that sovereignty. What is sovereign is simultaneously dominant and overlooked. In his interpretation of Velazquez's Las Meninas, for example, Foucault calls representation "that sovereign vanishing-point, indefinitely distant but constituent."4

Throughout The Order of Things, what is decisive in Foucault's analysis of the centripetal movement of sovereignty is that the essential structure and privilege of sovereignty remains furtive. It thereby escapes a critical examination within the classical episteme. Rather than effecting a qualitative transformation of the structure of sovereignty, the Classical Age merely privileges the individual, instead of the King, as sovereign, language instead of things, and the "I am" instead of the "I think." Foucault evinces how this privilege extends into at least five distinct spheres in all: (1) within the problem of representation; (2) within the "historical a priori" by which words and things are ordered; (3) within the sphere of the cogito; (4) within the domain of "man" as a constituting subject; and (5) within the hermeneutic of the authorial voice and textuality.

While space constraints do not permit elaboration of this theme in any great detail or allow much textual support for this thesis, Foucault's general point seems to be the following: while new representations of sovereignty were installed at the heart of its deployment, the same outmoded legitimating criteria substantiate its incursions into the Classical episteme. Foucault illustrates that even though different provincial authorities are held to be sovereign at different times, the net effect of this transition is simply the replacement of one delegation of sovereignty with another. He demonstrates that only the specific theater of the old sovereignty changes without this displacement really fracturing the structure of sovereignty itself.

\section{SOVEREIGNTY AND POWER IN THE WILL TO KNOW}

If power no longer resides in the old monarchies or their institutional apparatuses, if power can no longer be located in any unitary agencies whatsoever, then cutting off the King's head serves only to efface the symbolic figurehead of archaic principalities of power. In the classical conception of power, power is understood primarily as something to be possessed and wielded. Classical political theories treat power as a mode of agency or a substance resident in sovereign authority. Foucault maintains that such a view of power merely fastens upon the static symbols of the dynamic substrata he calls "power." What we see are only the effects of

4 Michel Foucault, The Order of Things (New York: Random House, 1970), 277. 
power. On the classical view, power is always bound up with a system of law and the production of discourses, but Foucault argues that law is itself only the end product of a power/knowledge relation. What is more problematic is that the connection of power to law fosters an entirely negative understanding of power. It reduces power to something that restrains, constructs defenses, and blocks the exercise of other powers. This paradigm misses the positive, productive, inert, and propagational capabilities of power altogether. And in Foucault's view, it is its productive character that enables power to escape our notice while nonetheless proliferating and reconstellating in new forms and in more sophisticated guises.

For Foucault, power does not reside primarily in governments, militaries, police, political office, or any of the other institutions traditionally thought to harbor it. It cannot even be made fully transparent by analyzing the institutions Foucault himself examines: prisons, hospitals, clinics, and asylums. Institutions are, he says, only the "terminal forms power takes" (92). He insists that we must begin to conceive the techniques of power as polymorphous and ubiquitous; wherever we look, power relations are "always already present" (82). If we must conceive of power without the King, as Foucault maintains, we cannot attribute the "real" power to the legislator, either, as power is, in a sense, its own "law," and because Foucault wants to sever the exclusive connection of power to law. This means that the shift in the locus of sovereignty in the Classical Age--from the monarch to the more amorphous authority found in law--must still be supervened by the subsequent analysis of power that dislodges power from such juridico-discursive systems. In Foucault's view, the instantiation of power as law is a secondary example of power.

His stated objective in The Will to Know is to move toward "a definition of the specific domain formed by relations of power, and toward a determination of the instruments that will make possible its analysis" (82). This analysis can be constituted, he says, "only if it frees itself completely from a certain representation of power that I would term ... 'juridicodiscursive"' (82). The juridico-discursive model of power has defined most political approaches to power prior to Foucault. Political philosophy has traditionally understood power as a perquisite of legitimate authority. On this view, power derives from law in order to be legitimate. Illegitimate power is arbitrary and falls outside of, or runs counter to, established law. 5 Law derives its authority, in turn, from either a conception of natural right or consent. When authority is "legitimate," power and law are

5 Foucault does point out the irony in the way that absolute monarchy is viewed as illegitimate, even though it has its origin in law. See his discussion of this issue in The History of SexualitY, V.I. pp. 87-88. 
coextensive. On this base/superstructure schema, power is thought to flow vertically. Countless sociopolitical theories of power have been constructed and analyzed on the basis of this model. Foucault shuns such a conception of power (94), maintaining that

It is this image that we must break free of, that is, of the theoretical privilege of law and sovereignty, if we wish to analyze power within the concrete and historical framework of its operation (90).

Since, for Foucault, "power is everywhere" (93), questions of legitimacy are as vacuous as an inquiry into the legitimacy of gravity or atmospheric conditions. For him, power relations are equally inescapable. Furthermore, if institutions where we traditionally look to uncover power serve only as power's terminal points, then one cannot explain what power is merely by enveloping traditional institutions in a veneer of authority. Foucault argues that to really understand power, we need to deploy methods "that go beyond the state and its apparatus" (89).

Following this methodological imperative, Foucault's analysis disinters power from the privileged settings in which it has been conceptually embedded up to this point. The problem is that power cannot be made fully concrete even by analyzing the normative or punitive apparatuses of any complex relation of power and knowledge. Distinguishing his view from the classical understanding of power, Foucault writes:

\section{by power, I do not mean "Power" as a group of institutions and mechanisms that ensure the subservience of the citizens of a given state. By power, I do not mean, either, a mode of subjugation which, in contrast to violence, has the form of the rule. Finally, I do not have in mind a general system of domination exerted by one group over another (92).}

The challenge here is to abandon any definition that equates power with institutions, law, or the various techniques of subjugation and domination exercised by one individual or group over others.

This juridico-discursive model, according to Foucault, continues to underlie "recent analyses concerning the relationships of power to sex."6 Taking the juridico-discursive paradigm for granted has given

6 Ibid., p. 89. For Foucault, psychoanalysis from Freud to Lacan has failed to extricate sex from the old techniques of power. I will return below to this problem. Cf. also Part 5 of The Will to Know. 
rise to the focus upon desire as a sort of "natural law." Foucault vitiates the notion of "desire" for not being fundamental enough insofar as it assumes the status of a law. Whatever "desire" is, it is itself produced by, and constructed within, power relations. Foucault writes, "Where there is desire, the power relation is already present" (81). It is not a matter, however, of determining whether desire is prior to a framework of law or alien to it; these questions are beside the point. In Foucault's view, such an approach continues to situate desire in relation to a notion of power that remains juridical and discursive, a power that still has its primary efficacy "in the enunciation of the law" (90).

Foucault understands power as something relational. He describes power as traversing through a "multiplicity of force relations" (93). It cannot be reduced to a single origin or telos; it insinuates itself into, and courses through, constantly mutable interstices of those force relations. ${ }^{7}$ Power, for Foucault, is "the moving substrata of force relations"(93), having no "inner" or "outer" domain. If we say metaphorically that we are "within" power relations, then we must be clear that there is no exteriority to such relations. In Foucault's view, we are always already within a particular interstitial coalescence of power dynamics that one may sometimes transgress, and occasionally transform, but never escape.

Likewise, each set of discourses and practices produces others with new discourses erupting within the shifting constellations of power. According to Foucault, we conduct ourselves within a network in which all discourses can be viewed as interlocking and hierarchized articulations of power relations. There is a kind of symbiosis or synergy between power and discourse, wherein new "enunciative modalities" represent necessary conditions for the operation of new strategies of power.

What is more, each constellation of discourses and practices delimits and supports its particular standard of truth. This means that, for Foucault, truth does not exist outside of a complex relation of power/knowledge. Since any claim to truth has purchase only within a particular power/knowledge relation, truth cannot be thought to control, constrain, or judge power. For Foucault, truth and power are inextricably bound together; power's exercise and the construction of truth are intertwined and coterminous. 8

7 Foucault gives his clearest definition of power on pp. 92-93 of The History of Sexuality V.I, at the very beginning of the section entitled "Method."

8 See especially the essay, "Power and Truth," in Power/Knowledge: Selected Interviews and Other Writings (1972-1977), 109-133. Foucault vitiates the humanistic position, which rests on an unshakable faith in the progress of history, and on the belief in an inner being of man that needs to be liberatcd or uncovered. For Foucault, it is an illusion to assume that philosophy can stand outside of 
Nowhere is the conjunction of the exercise of power and the fabrication of truth more explosive than in the domain of sexuality. Foucault argues that since the end of the eighteenth century, the mechanisms of power have been directed toward the proliferation and control of life and the body rather than blood and death. He terms this modern deployment of power the "analytics of sexuality" and sees it as engendering "an entire micro-power concerned with the body" (146). This modern form of power has delineated, according to Foucault, an extensive matrix of "comprehensive measures, statistical assessments, and interventions aimed at the entire social body or at groups taken as a whole" (146).

Foucault depicts how the construction of sexuality within a shifting nexus of power relations insures that power's tactics will permeate every aspect of individual existence. He maintains that the politics of sexuality have generated an entire complex of disciplines intersecting the body that serve to regulate the body-politic. Foucault sees a wide range of tactics combining within what he terms a "technology of sex." This technology serves the dual objective of "disciplining the body" and of "regulating populations" (146).

In a loosely historical manner, Foucault argues that for the last two hundred years, but especially since the end of the nineteenth century, sex has functioned as the point of convergence between the control of the body and control of the species. ${ }^{9} \mathrm{He}$ argues that it is no longer the right over death that is the exclusive jurisdiction of sovereignty but the control over life. When power could be justifiably connected to law and sovereignty, it appeared as a symbolism of blood that reached its most fatal concretization in the monarch's sword. But, for Foucault, the axis of power has shifted since the Classical Age from this "symbolics of blood to an analytics of sexuality" (148). He sees blood, law, death, transgression, and sovereignty as characterizing one deployment of power and an altogether different set of strategies to be connected with sexuality, norms, knowledge, life, and regulatory power (148). As the procedures and strategies of power change, so must the methods of

discursive formations. He argues that such presumptive distancing is impossible, because there are no objects or values prior to, or outside of, a domain of discourse. We are always already within a complex relation of power/knowledge that, as perforce a regime of truth, prefigures what counts as true within that constellation of power and knowledge. Foucault shows this systematically in Chapter 2 of The Archacology of Knowledge, where he treats the way these "discursive formations," "enunciative modalities," or "historical a priori's" are engendered. He continues by showing how various norms are established within a particular regime of power, and how each regime enforces compliance to these norms.

9 Foucault writes, "Sex was a means of access both to the life of the body and the life of the species." See The Will to Know, 146. 
its analysis. The failure to adapt one's methodology to the innovative methods of power is at the heart of Foucault's critique of Freud, for example, whose retrieval of the idea of desire reveals what Foucault describes as "the theoretical effort to reinscribe the thematic of sexuality in the system of law, the symbolic order and sovereignty" (150). Whether or not Foucault's argument is more theoretical than historical, he wants to insist that the methods of the deployment of sexuality differ from the methods of the deployment of the symbolics of blood. The procedural requirement this difference creates cannot be overlooked if we really wish to account for power. "We must," Foucault writes, "conceptualize the deployment of sexuality on the basis of the techniques of power that are contemporary with it" (150).

Foucault explains that the movement from law as the locus of sovereignty to life itself was accompanied by an entirely unique implementation of power. He says that these two different formations of power grew out of wholly different regimes of power, though there are inevitable overlappings and interactions between them. Nonetheless, he endeavors to deconstruct the old couplings of power-law and power-sovereignty, eschewing them as inadequate to the task of understanding the infiltration of power's various interdictions into sexual behaviors and practices. In short, the juridico-discursive model of power has outlived its usefulness. Even when the tactics of power were organized primarily around death, law, right, and punishment, Foucault does not seem to consider this account of power to be exhaustive. But now that regulation, normalization, and control describe the methods of power's operation, it is clear that any analysis of power must be able to expose tactics that do not terminate in the state apparatus.

The old juridico-discursive model of sovereignty misses entirely the subtle domination of ubiquitous power that infiltrates every aspect of life. Most of all, it misses the productive potential of the new forms of power, the pervasive capability of creating and propagating rather than simply restraining or denying. Foucault emphasizes this productive dimension of power, which first arouses and then delineates the universal concern with sex only thereby to exercise dominion over both the body and the body-politic. To grasp the gratuitous proliferation of discourses around sex would seem to necessitate a highly mobile conception of power, and this is what Foucault struggles to adumbrate in the theoretical first volume of The History of Sexuality. Foucault explicates the theoretical consequence of the shifting strategies of power throughout this work. What he calls the "viewpoint of the objective" supplants the privilege of the law, "tactical efficacy" replaces prohibition, and the classical conception of sovereignty gives way to his analysis of a "multiple 
and mobile field of force relations, wherein far-reaching, but never completely stable, effects of domination are produced" (102).

In Part 5 of The Will to Know, Foucault increasingly marshals the dynamics of power to highlight the techniques of normalization and control. He is not claiming that law and institutional apparatuses disappear or recede completely in significance but rather that "the law operates more and more as a norm," while juridical institutions are incorporated more and more into a "continuum of apparatuses (medical, administrative, and so on) whose functions are for the most part regulatory" (144).

With his notions of "anatomo-politics" and "bio-power," Foucault shows that the question of sovereignty is no longer a question of bringing death upon political subjects or, conversely, of letting them live; the sovereign no longer needs to control death by employing the sword to draw the line between the obedient subjects and the enemies of the ruler or state. When sex is sovereign, the task of power becomes one of "distributing the living in the domain of value and utility. Such a power has to qualify, measure, appraise, and hierarchize, rather than to display itself in its murderous splendor" (144). Foucault's analysis of a normalizing society brings together the body and his theory of power. He holds that a new form of power emerges when the technology of power centers upon life.

When the mechanisms of power are directed toward the body, and through the body, to the body-politic, to the generation of life, and to sex as the juncture of pleasure and preservation, the result is a strategy of power in the twentieth century that, for Foucault, forms and stylizes the most intimate, far-reaching, and ready to hand behaviors of human life. But if sexuality is a construction of, and within, power, this would imply that there can be no constant, intrinsic norm for sexuality but only various "sexualities," and these are never independent of power relations. The social, political, and economic construction of sexuality renders sex an instrument of power's design (150).

Only by radically questioning the presupposition of sex as an "anchorage point that supports the manifestations of sexuality," Foucault writes, can we ever reconstruct such a "complex idea formed inside the deployment of sexuality" (152). His project strives to exhibit the formation of sexual identities through the production and regulation of discourses and practices that develop within the diverse and camouflaged syncretizations of power.

Foucault's conclusions about the conscription of the body and the machinery of the body-politic by the systems for the production of normalcy afford this inquiry a position from which to tally several important results. We have distinguished "sovereignty" from "power," tracing how the sovereignty of sex comes to replace the 
juridico-discursive sovereignty of blood in The Will to Know. We have followed Foucault in considering power as a complex, relational dynamic that remains when we do away with the image of the King or the Prince. We have also seen that, for Foucault, the strategies of power are not constant but vary according to their structure and locus. Finally, we have noted briefly that, for Foucault, the complex construction of "sexuality" assumes divergent forms and employs a myriad of local efficacies for inscribing itself within social bodies.

In my view, the radicality and strength of Foucault's analysis lies chiefly in the way it traces the diffuse tactics of regulation and normalization into the discourses and practices of the modern era. What remained the province of the juridico-discursive sovereignties within the Classical Age has become more fragmented and ubiquitous, more productive and regulatory. Foucault's critique of the humanistic ideal of emancipation issues from his genealogy of this inescapable system of power. As we have seen, the techniques of power aim to foster normalcy through interventions in the domain of everyday discourses and practices. The discipline that power engenders is more aptly characterized by the production of acceptable behaviors than by the constant effort to check the impulses to misbehave. In the face of this self-discipline, punishment is no longer necessary. Under the weight of such exhaustive and preemptive self-control, we strive to demonstrate that we are not in need of any additional regimens or "treatments." Without transforming Foucault into a critical theorist, we could say that we struggle to display ourselves as responsible agents who require no rehabilitation. For Foucault, the irony is that while we organize and order ourselves all the more rigidly within what he calls the "austere monarchy of sex" (159), we labor under the illusion that it is our "liberation" that hangs in the balance. 